\title{
DEVELOPING A MACHINE FOR FERTILIZING VEGETABLE CROPS WITH COMPOST
}

${ }^{1}$ R. A. Werby, ${ }^{2}$ A. K. Zaalouk, ${ }^{3}$ I. S. Soaly, ${ }^{4}$ M. A. Mosallm, and ${ }^{5}$ M. M. Elewa

\section{ABSTRACT}

The objective of the present work was to develop and evaluate fertilizing machine for vegetable to make under Egyptian condition. The fertilizing machine was evaluated versus four forward speeds (2.8, 3.2, 3.6, and 4.0 $\mathrm{km} / \mathrm{h})$, three feeding areas $\left(50,100\right.$, and $\left.150 \mathrm{~cm}^{2}\right)$, three fertilizing depths $(15,20$, and $25 \mathrm{~cm})$ and two bully diameters with land wheel (15 and 25 $\mathrm{cm})$. The results showed that the highest productivity was $31.11 \mathrm{~m}^{3} / \mathrm{fed}$; and $82.84 \%$ fertilizing homogeneous fertilizing obtained at $2.8 \mathrm{~km} / \mathrm{h}$ forward speed, $150 \mathrm{~cm}^{2}$ feeding area, $25 \mathrm{~cm}$ fertilizing depth and bully diameter with land wheel $15 \mathrm{~cm}$. The best result field efficiency was $85.12 \%$ and minimum specific energy $31.41 \mathrm{~kW}$.h/fed at obtained forward speed $4 \mathrm{~km} / \mathrm{h}, 150 \mathrm{~cm}^{2}$ feeding area, $15 \mathrm{~cm}$ fertilizing depth and bully diameter with land wheel $15 \mathrm{~cm}$. The maximum consumption and operation cost was $128.78 \mathrm{LE} / \mathrm{fed}$; and $5.79 \mathrm{LE} / \mathrm{m}^{3}$.

\section{INTRODUCTION}

During the last decade a great deal of attention gave to reclaim new lands (desert lands) and grow these lands by vegetable crops whereas these crops are considered to be of height income in short rotation. Further, increase in vegetables production by increasing the yield par is required by controlling the amount of fertilizer application. Ismail (2011). Weed and Kanwar (1996) reported that the compost and agricultural management practices are important factors that strongly affect soil properties and water entry, and subsequent nutrients cycling processes in the soil profile. Moursy et al. (2001) indicated that application of tomato plant CV super manmade with organic manure (cattle under ElMinia condition manure and plant residues composite, at $20 \mathrm{~m}^{3} / \mathrm{fed}$,) increased growth parameters (plant height and number of branches/plant).

1- Assoc. prof. of Agri., Fac. Of Agri. Eng., Al-Azhar U.

2- Prof. and Head of Agri . mach . and Powr Eng., Dep. Al-Azhar U

3- Dean of Agric. Eng-Al-Azhar U.

4- Prof. Emt. Of Agri., Eng. Fac. Of Agric. Eng., Al-Azhar U.

5- Grade Student of Agric. Eng . Dept ., Fac. Of Agric., Al-Azhar U. 
El-Bahraw (1998) showed that the Physical properties of fertilizer such as: angle of repose, friction angle and shape; bulk density and moisture content are the important factors in determining the distribution uniformity. El-Attar (1995) designed and fabricated self-propeller liquid and organic fertilizer machine for small holding; The fabricated machine consists mainly of power tiller (14 hp), a one-axial compost spreader, device to mix the compost with the soil and injection unit. The investigation corroborate many advantages of the fabricated machine such as low lab our requirement, low cost, high uniformity of distribution and suit to the small farms of Egypt. Salama (2016) indicated that the using of the fertilizer machine at forward speed of $3.3 \mathrm{~km} / \mathrm{h}$, rotating speed of $120 \mathrm{rpm}$ and furrow depth of $20 \mathrm{~cm}$ gave the best result $(5.44 \mathrm{Mg} / \mathrm{fed}$;) compared with other treatments. While the using of the traditional method gave the lowest value of productivity $(3.97 \mathrm{Mg} / \mathrm{fed}$;).And lowest value was $366.06 \mathrm{~kW} . \mathrm{h} / \mathrm{fed}$ at furrow depth of $15 \mathrm{~cm}$ and forward speed of 3.3 $\mathrm{km} / \mathrm{h}$. The main objective of the present work is to develop a machine locally made compost fertilizing and study some engineering factors affecting compost fertilizing machine and evaluating the performance of developed machine.

\section{MATERIAL AND METHODS}

The fertilizing machine was manufactured at local worksops and the experiments were carried out at farm located in Elam village, Ismailia Governorate, Egypt for the season of 2015-2017.

\section{1-Type of fertilizer:}

Experiments were carried out on compost fertilizing. Some physical and mechanical properties of listed in Table (1)

Table (1): Some properties of the compost fertilizer.

\begin{tabular}{|c|c|}
\hline Fertilizer properties & Compost fertilizer \\
\hline Colour & brown \\
Consistency & sponge \\
Form of fertilizer & sponge \\
Moisture content, $\%$ & $6-8$ \\
Friction angle & $45^{\circ}$ \\
Repose angle & $42^{\circ}$ \\
Bulk density, $\mathrm{kg} / \mathrm{m}^{3}$ & 720 \\
\hline
\end{tabular}




\section{2-The fertilizing machine:}

The fertilizing machine was constructed of frame and wheels; compost box and agitator; furrow opener and covering device; feed unit, and control gate. The constructed of a fertilizer machine was carried at local workshop. The technical specification and operating parameters of fertilizering machine is shown in Fig (1) and Table (2).

Table (2) Technical specification of the fertilizer machine.

\begin{tabular}{|c|c|}
\hline Item & Specification \\
\hline Main dimensions : & 170.0 \\
Overall width $(\mathrm{cm})$ & 284.5 \\
\hline Overall leigth $(\mathrm{cm})$ & 161.0 \\
\hline Overall height $(\mathrm{cm})$ & 735.0 \\
\hline Total mass $(\mathrm{kg})$ & 150.0 \\
\hline Fertilizer width $(\mathrm{cm})$ & \\
\hline
\end{tabular}

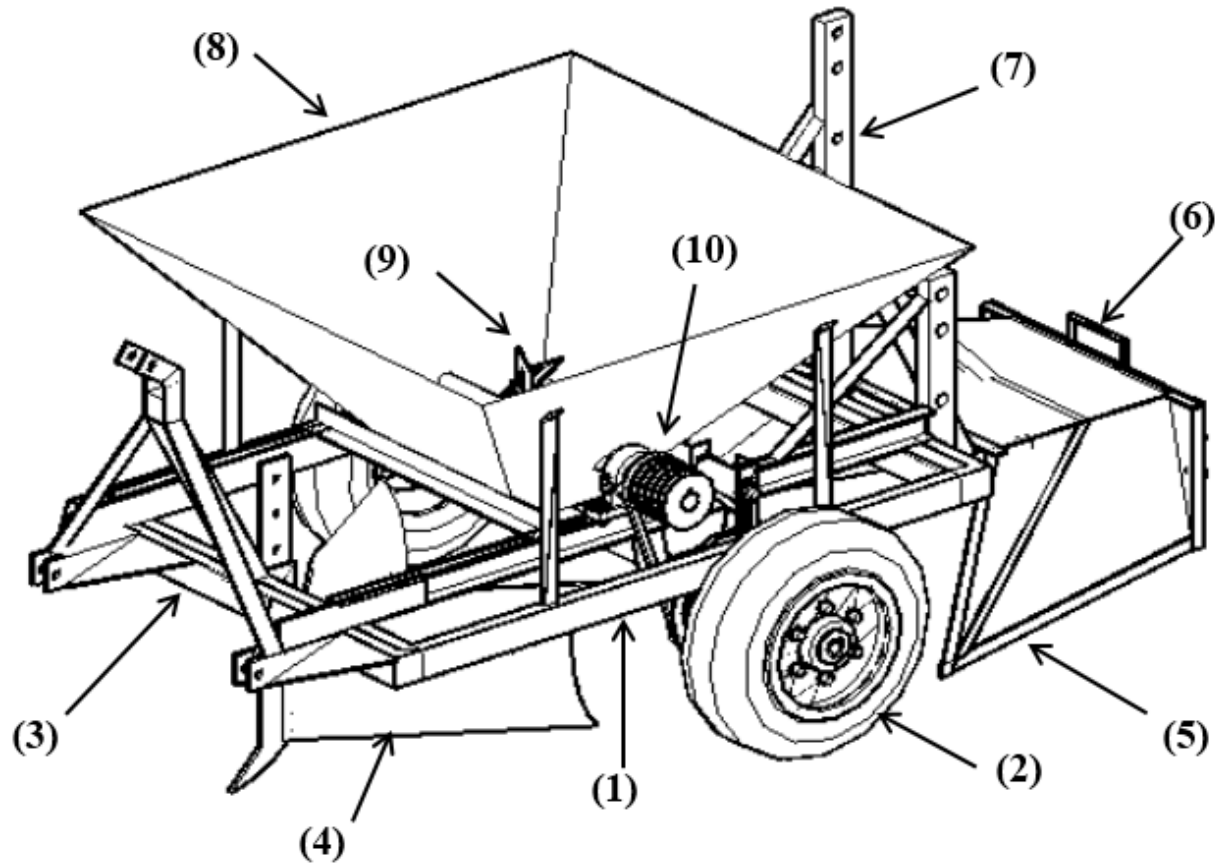

1- Frame; 2- Wheels; 3- Hanging points with tractor; 4- Furrow opener; 5Covering device; 6-Controller in level of covering; 7-Hanging points with covering device ; 8- Compost box; 9- Agitator; 10- Moving transporter

Fig. (1): Components of the fertilizing machine. 
The effect of the following variables on the fertilizing machine productivity, specific energy requirement and fertilizing homogeneous for compost were studied :

1- Four forward speed of 2.8, 3.2, 3.6, and $4.0 \mathrm{~km} / \mathrm{h}$.

2- Three feeding area 50,100 , and $150 \mathrm{~cm}^{2}$.

3- Three fertilizing depth 15,20 and $25 \mathrm{~cm}$.

4- Two bully diameter with land wheel 15 and $25 \mathrm{~cm}$.

\section{1- The fertilizing rate:}

The application rate $(\mathrm{Q})$ in $\mathrm{kg} / \mathrm{fed}$, was determined form the following formula :

$Q=q / F_{e}, \mathbf{k g} /$ fed.

Where :

$\mathrm{q}$ : The feed rate of compost, $\mathrm{kg} / \mathrm{h}$

$\mathrm{F}_{\mathrm{e}}$ : The field capacity, fed; / h.

\section{2 - The compost distribution homogeneity}

Sufficient samples were taken for each experiment:

Homogeneity is calculated by determining both maximum and minimum sample, then calculating the deviation between maximum sample and mean and also between minimum sample and mean then the greater value is divided by mean and multiplying by 100 . It can be also explained as following (Coates and Tanaka 1992)

1-Determine maximum sample

2-Determine minimum sample

3-Deviation between maximum and mean

4-Deviation between minimum and mean

Homogeneity $=\frac{\text { The greater of } \operatorname{step}(3) \text { or }(4)}{\text { Mean }} \times 100$

\section{3- Actual field capacity:}

Actual field capacity is the actual average rate of coverage by machine, based upon the total effective operation time. It is a function of the rated width of the machine, the percentage of rated width actually utilized, the speed of travel, and the field time lost during operation (Kepner et al. 1978). Thus, it was calculated as: 


$$
A_{f c}=1 / T_{t}
$$

Where:

$\mathrm{A}_{\mathrm{fc}}$ : Actual field capacity, fed,/h.

$\mathrm{T}_{\mathrm{t}}$ :Total effective operating time, $\mathrm{h} / \mathrm{fed}$

\section{4 - Energy:}

The following formula was used to estimate the engine power according to (Embaby, 1985):

$$
\mathrm{Ep}=\mathbf{f . c} * 2.767
$$

Where:

EP: Engine power, $\mathrm{kW}$.

f.c: Fuel consumption, L/h.

$E_{R}=E P / A f c$

Where:

$\mathrm{E}_{\mathrm{r}}$ : Energy requirements, $\mathrm{kW} . \mathrm{h} / \mathrm{fed}$.

EP: Engine power, $\mathrm{kW}$.

$A_{\text {fc: }}$ : Actual field capacity, fed/h.

\section{5 - Total cost :}

The following relationship was developed by (Awady 1978) to estimate the hourly cost of tractor operation:

$$
\begin{aligned}
& \mathrm{C}=\left[\frac{p}{h}\right] *\left[\frac{1}{l}+\frac{i}{2}+t+r\right]+[1.2 * \mathrm{RFC} * \mathrm{f}]+\left[\frac{m}{144}\right]+\left[\frac{p 1}{h 1}\right] * \\
& {\left[\frac{1}{l 1}+\frac{i}{2}+t+r 1\right] \ldots \ldots \ldots \ldots . . .(5)}
\end{aligned}
$$

Where:

$\mathrm{C}$ : Cost per hour of operation, $\mathrm{LE} / \mathrm{h}$.

P: Initial price of the tractor, (350000 LE).

$\mathrm{h}$ : Yearly working hours of tractor, (1000h).

L: Life expectancy of the tractor, (10years).

i: Annual interest rate, (10\%).

$\mathrm{t}$ : Annual taxes and overheads ratio,(3\%).

$\mathrm{r}$ : Annual repairs and maintenance ratio for tractor, $(10 \%)$.

f: Fuel price, (3.65 LE/L)

m: Operator monthly salary,(1500 LE/month).

1.2: Factor accounting for lubrication. 
144: The operator monthly average working hours, $h$.

RFC: The actual rate of fuel consumption $\mathrm{L} / \mathrm{h}$.

P1: Initial price of the fertilizing machine, (12000LE).

h1: Yearly working hours of the fertilizeng machine, (750 h/year).

L1: Life expectancy of the fertilizng machine,(10 year).

r1: Annual repairs and maintenance ratio for the machine, $(1 \%)$.

Total cost per unit area of the experimented machine:

$\mathbf{T}_{\mathbf{c a}}=\mathrm{C} /$ Afc

Where:

$\mathrm{T}_{\mathrm{ca}}$ : Total cost of unit area, LE/fed.

Afc: Actual field capacity, fed;/h.

C: Cost per hour of operation, LE/h.

\section{RESULTS AND DISCUSSIONS}

\section{1- Fertilizing rate:}

Fig (2) illustrates the relationship between the fertilizing rate values $" F_{z}$ " affected by feed open area " $F_{a}$ ", fertilizing depth " $F_{d}$ ", bully diameter with land wheel " $\mathrm{B}_{\mathrm{d}}$ " at all forward speeds "S". The maximum value of fertilizing rate was $31.11 \mathrm{~m}^{3} / \mathrm{fed}$; at forward speed $2.8 \mathrm{~km} / \mathrm{h}$, feed opening area $150 \mathrm{~cm}^{2}$, fertilizing depth $25 \mathrm{~cm}$ and bully diameter with land wheel $15 \mathrm{~cm}$; while the minimum value of fertilizing rate was $1.56 \mathrm{~m} 3 / \mathrm{fed}$; at forward speed $3.6 \mathrm{~km} / \mathrm{h}$, feed opening area $50 \mathrm{~cm}^{2}$, fertilizing depth 25 $\mathrm{cm}$ and bully diameter with land wheel $15 \mathrm{~cm}$.

\section{2- Actual field capacity:}

Figure (3) illustrated the relationship between the actual field capacity "fact" (fed;/h) with forward speed "S" ( $\mathrm{km} / \mathrm{h}$ )at different feed open areas " $F_{a}$ " $\left(\mathrm{cm}^{2}\right)$, fertilizing depth " $F_{d}$ " $(\mathrm{cm})$ and bully diameter with land wheel " $B_{d}$ " $(\mathrm{cm})$.

The maximum value of actual field capacity was $1.22 \mathrm{fed}, / \mathrm{h}$ at forward speed $4 \mathrm{~km} / \mathrm{h}$, feed open area $150 \mathrm{~cm}^{2}$, fertilizing depth $15 \mathrm{~cm}$, and bully diameter with land wheel $15 \mathrm{~cm}$; while minimum value of actual field capacity was $0.66 \mathrm{fed} ; \mathrm{h}$ at forward speed $2.8 \mathrm{~km} / \mathrm{h}$, feed open area 100 $\mathrm{cm}^{2}$, fertilizing depth $25 \mathrm{~cm}$, and bully diameter with land wheel $25 \mathrm{~cm}$. 


\section{3-Energy requirements:}

Fig (4) illustrated the relationship between the energy requirements values $(\mathrm{kW} . \mathrm{h} / \mathrm{fed})$ affected by forward $\operatorname{speed}(\mathrm{S})(\mathrm{km} / \mathrm{h})$ at different feed open area $A_{f}\left(\mathrm{~cm}^{2}\right)$, fertilizing depth $F d(\mathrm{~cm})$ and bully diameter with land wheel $\mathrm{B}_{\mathrm{d}}(\mathrm{cm})$.

The results showed that energy requirement increased with increasing fertilizing depth and bully diameter with land wheel $\left(\mathrm{d}_{\mathrm{b}}\right)$; while decreased with increasing forward speed from 2.8 to $4 \mathrm{~km} / \mathrm{h}$ and feed open area from 100 to $150 \mathrm{~cm}^{2}$, respectively at all treatments.

The maximum value of energy used was $64.35 \mathrm{~kW} . \mathrm{h} / \mathrm{fed}$; at forward speed $2.8 \mathrm{~km} / \mathrm{h}$, feed open area $100 \mathrm{~cm}^{2}$, fertilizing depth $25 \mathrm{~cm}$, and bully diameter with land wheel $25 \mathrm{~cm}$; while minimum value of energy used was $31.41 \mathrm{~kW} . \mathrm{h} / \mathrm{fed}$; at forward speed $4 \mathrm{~km} / \mathrm{h}$, feed open area $150 \mathrm{~cm}^{2}$, fertilizing depth $15 \mathrm{~cm}$, and bully diameter with land wheel $15 \mathrm{~cm}$.

\section{4- Evaluation of fertilizing homogeneous:}

Fig (5) shows the relationship between the homogeneous values (\%) affected by forward speed(S) $(\mathrm{km} / \mathrm{h})$ at different feed open area $A_{f}\left(\mathrm{~cm}^{2}\right)$, fertilizing depth $d_{f}(\mathrm{~cm})$ and bully diameter with land wheels $B_{d}(\mathrm{~cm})$.

The results showed that homogeneous decreased with increasing forward speed from 2.8 to $4 \mathrm{~km} / \mathrm{h}$, fertilizing depth 15,20 and $25 \mathrm{~cm}$; and bully diameter with land wheel $15,25 \mathrm{~cm}$; while increased with increasing feed open area from 50 to $150 \mathrm{~cm}^{2}$ respectively at all treatments.

The maximum value of homogeneous values was $82.84(\%)$ at forward speed $2.8 \mathrm{~km} / \mathrm{h}$, feed open area $150 \mathrm{~cm}^{2}$, fertilizing depth $15 \mathrm{~cm}$, and bully diameter with land wheel $15 \mathrm{~cm}$; while minimum value of homogeneous values was $8.21 \%$ at forward speed $3.6 \mathrm{~km} / \mathrm{h}$, feed open area $50 \mathrm{~cm}^{2}$, fertilizing depth $25 \mathrm{~cm}$, and bully diameter with land wheel $15 \mathrm{~cm}$;

5 - Cost of machine usage: The researchers recommend using fertilizing machine with forward speed $4 \mathrm{~km} / \mathrm{h}$, feed open area $150 \mathrm{~cm}^{2}$, fertilizing depth $15 \mathrm{~cm}$ and bully diameter with land wheel $15 \mathrm{~cm}$ the higher total cost per Fedden was ( 128.78 LE/fed). 
Bully diameter with land wheel $15 \mathrm{~cm}$
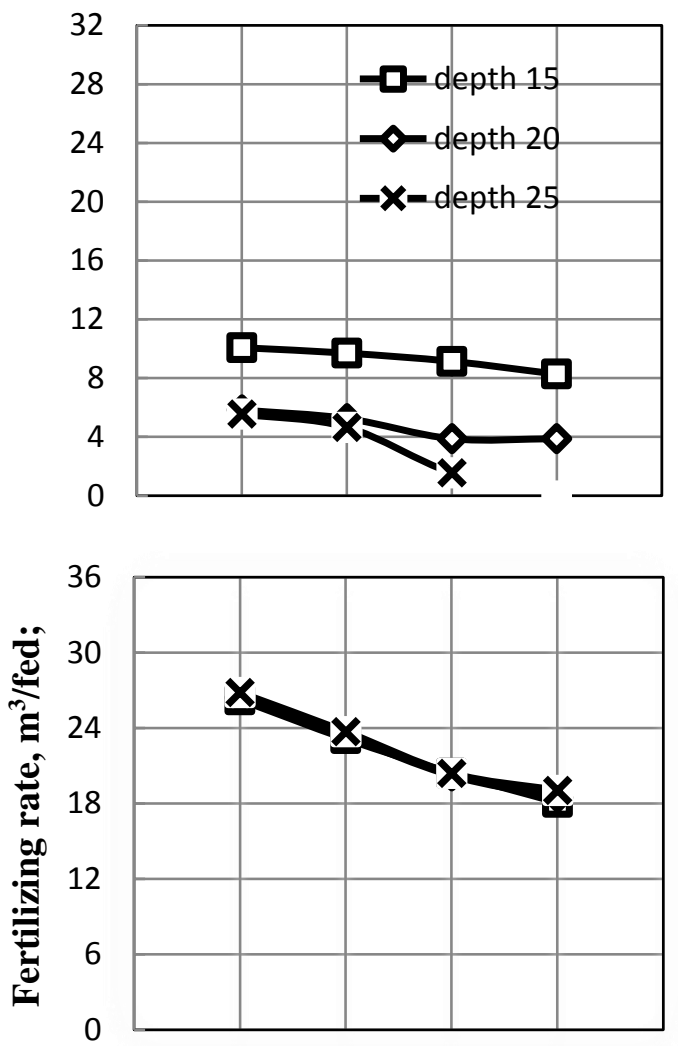

32

28

24

20

16

12

8

4

0

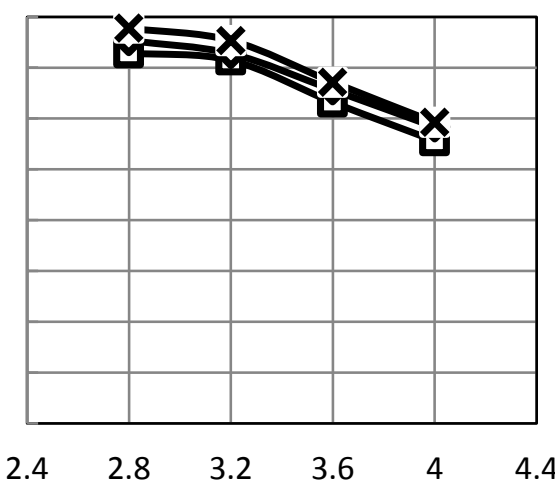

Bully diameter with land wheel $25 \mathrm{~cm}$
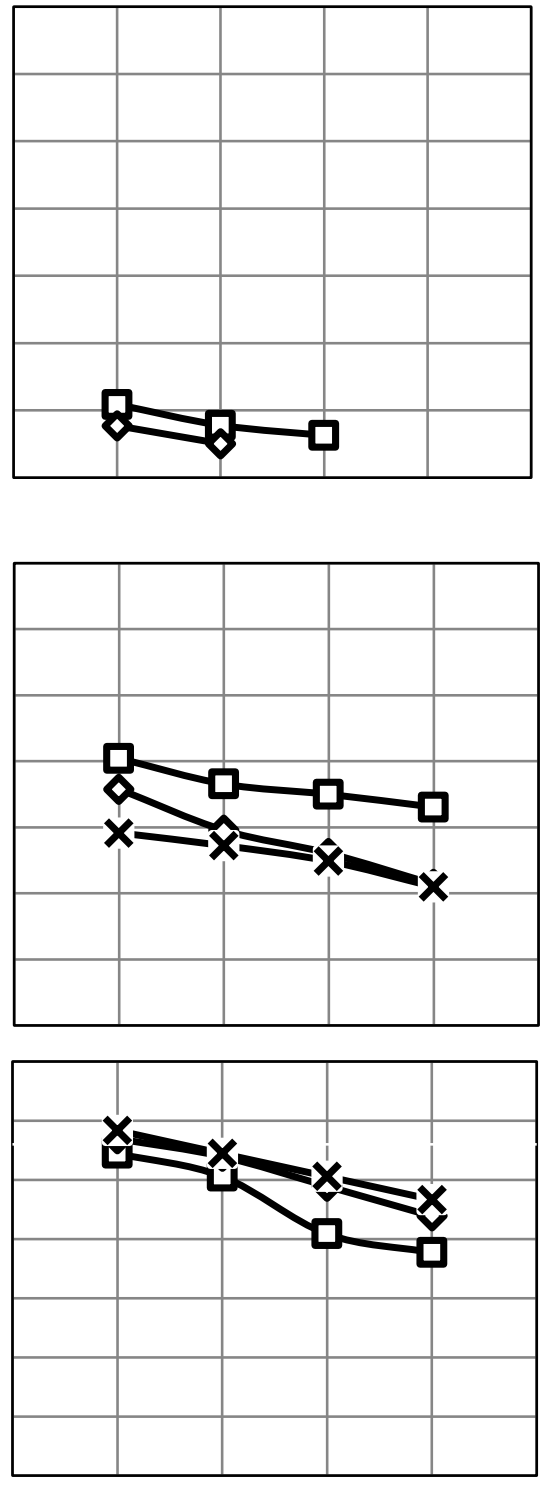

Forward speed (S), km/h

Fig. (4.2): Fertilizing rate $F_{Z}$ forward speed at different open feed areas, fertilizing depth and bully diameter with land wheel. 
Bully diameter with land wheel $15 \mathrm{~cm}$

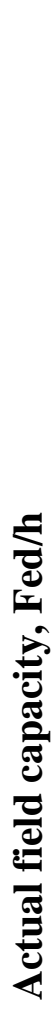

Bully diameter with land wheel $25 \mathrm{~cm}$
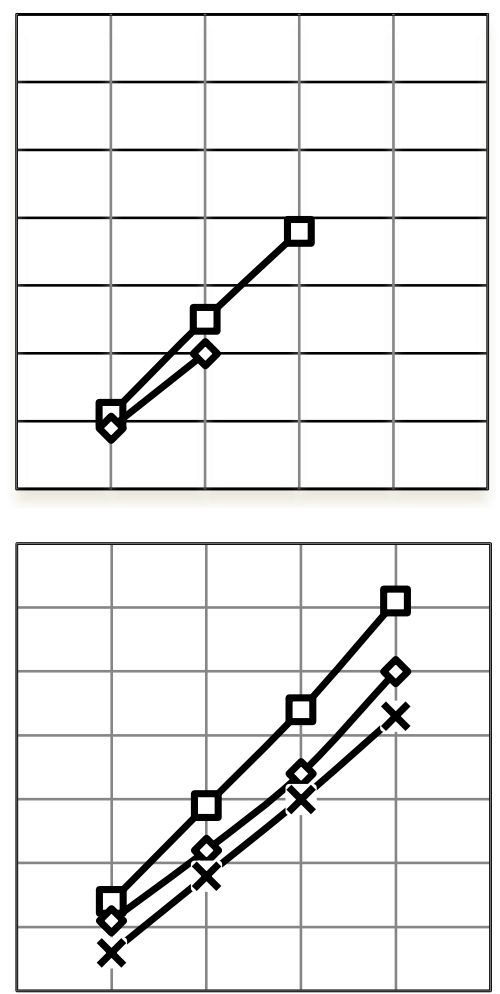

100

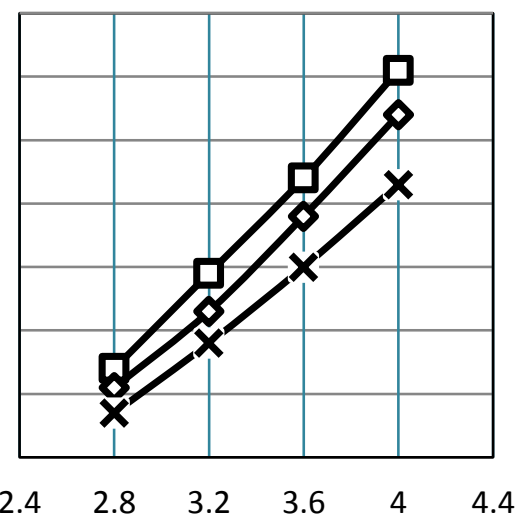

Forward speed, km/h

Fig. (4.3): Actual field capacity (VS) forward speed at different fertilizing depths, bully diameter with land wheel and open feed areas. 
Bully diameter with land wheel $15 \mathrm{~cm}$
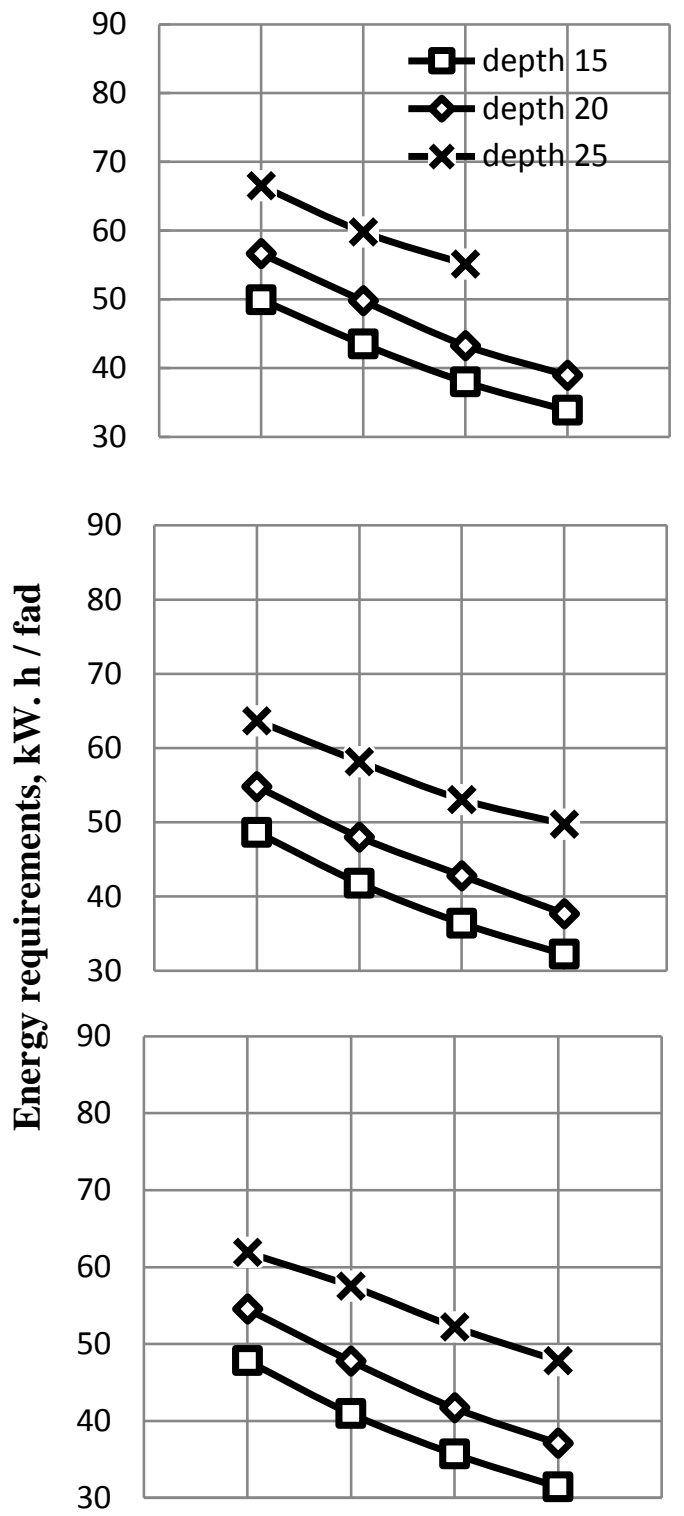

$\begin{array}{llllll}2.4 & 2.8 & 3.2 & 3.6 & 4 & 4.4\end{array}$
Bully diameter with land wheel $25 \mathrm{~cm}$

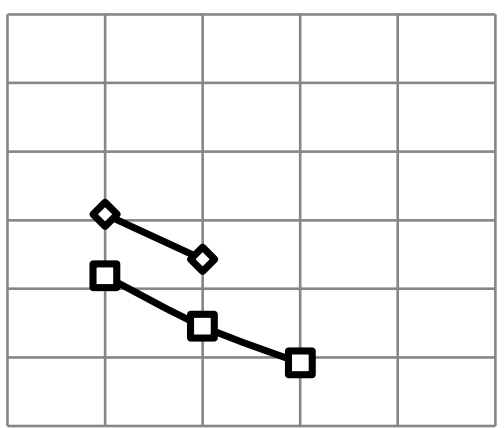

50

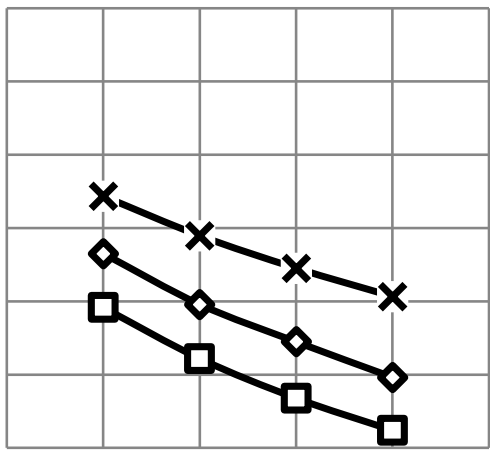

100

हैं

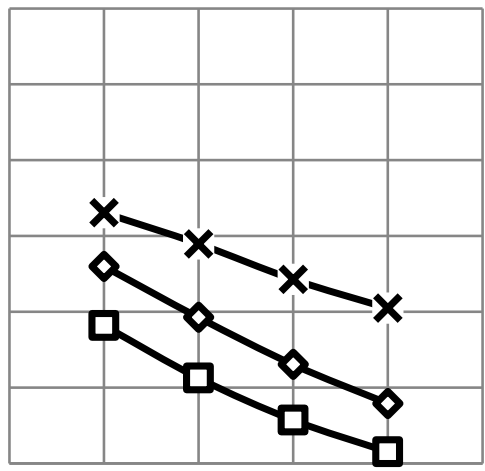

Forward speed, km/h

Fig.(4.4): Energy requirements Vs forward speed at different fertilizing depths, bully diameter with land wheel and feed opening areas. 
Bully diameter with land wheel $15 \mathrm{~cm}$
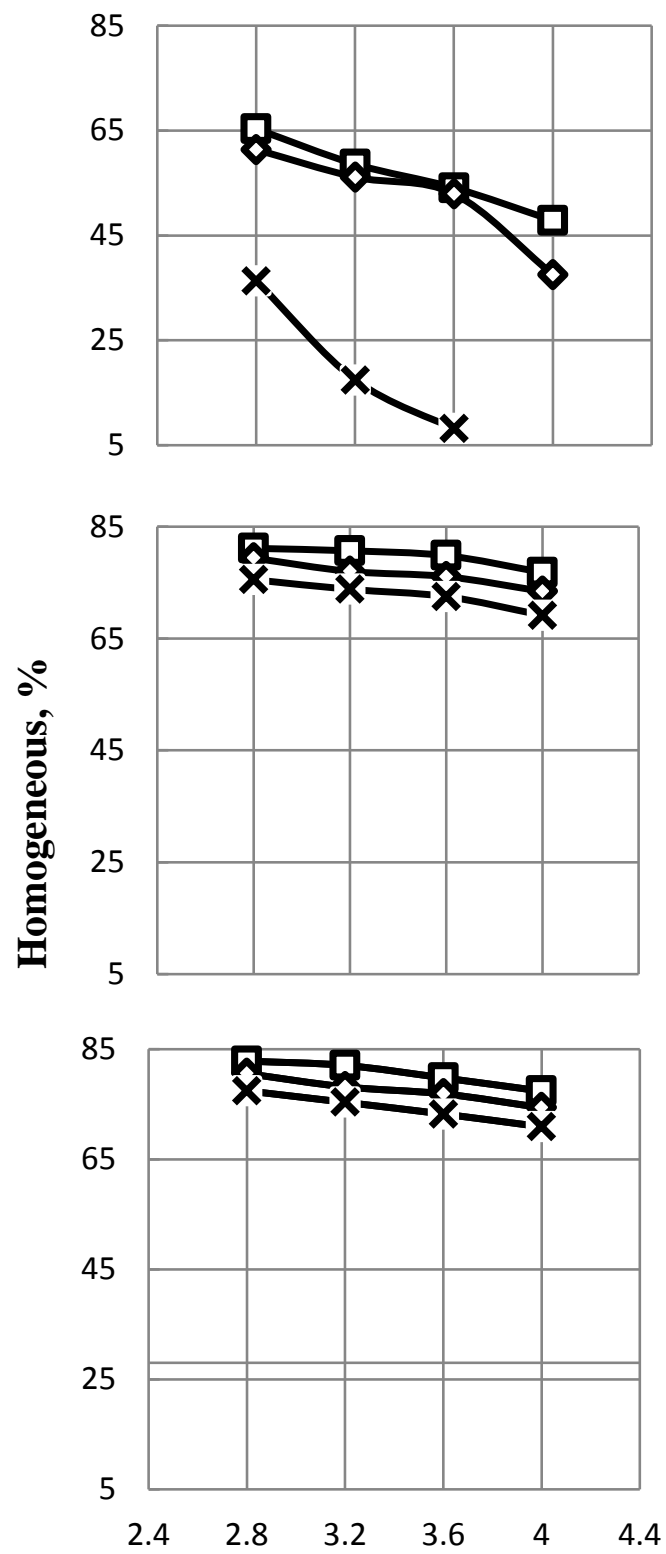

Bully diameter with land wheel $25 \mathrm{~cm}$

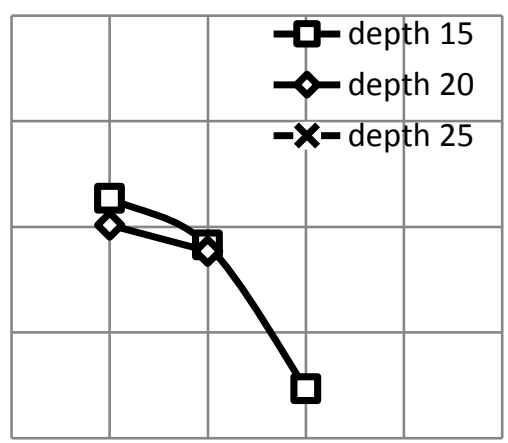

50

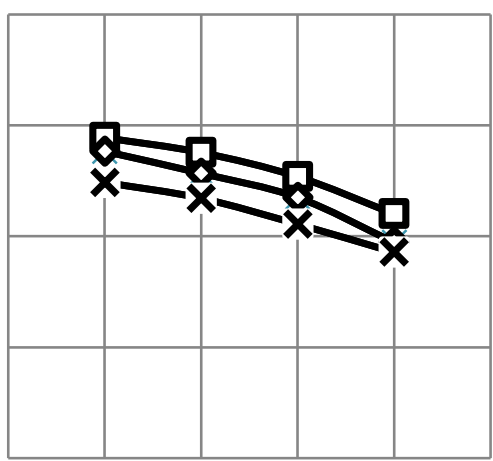

100

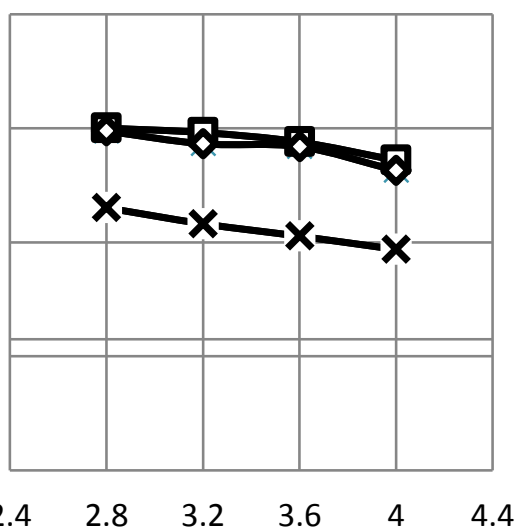

150

Forward speed, $\mathbf{k m} / \mathbf{h}$

Fig. (4. 5): Homogeneous (VS)forward speed at different fertilizing depths, bully diameter with land wheel and feed opening areas. 


\section{REFERENCES}

Awady, M.N. (1978). Tractor and farm machinery. Textbook, Faculty of agriculture, Ain Shams University, P:164-167.

Coates,P.M.and K.Tanaka (1992). New developments is fatty acid oxidation . New York : willey-Liss.

EL-Attar, M.A.I. (1995). performance of self-propeller liquid and organic fertilizers machine for smallholdings. Ph. D. Thesis. Ain. Shams Univ.

El-Bahrawy, B.M.S.(1998). study of factors affecting performance of the fertilizing machine in citrus orchards. Ph. D. Thesis. Zagazig Univ.

Embaby, A.T. (1985). A comparison of the different mechanization system for career crop production. Master of science thesis, agriculture engineering department, Faculty of agriculture, Cairo University.

Ismail,Z.E (2011) Fertilizer applicator evaluation using the response surface methodology. Misr J. Ag. Eng. 28(4): 759-781).

Kepner, R.A. Bainer and E.L. Barger (1978). Principles of Farm Machinery. 3rd ed., the AVI pub. Co., INC.Westport, CT., pp317.

Moursey, M.A, S.H. Gad El-Hak, Y.T. Abd El-Magid and A.A. Sadek.(2001) . Response of tomato to organic fertilization and mulching under Ei-Minia Governorate condition . The Fifth Arabian Horticulture conference, Ismailia Egypt, March, 24-28.

Salama , M.A. (2016); Manyufacture of alocal machine to apply organic and chemical fertilizers for vegetbles cultivationin sandy soil, ph. D. Facaulty of agriculture, Zagazig university.

Weed, A.J. and R.S. Kanwar.( 1996). Nitrate and water present in and flowing from root-zone soil. J.Qual. 25 (4):709-719. 


\section{الملخص العربي}

\section{تطوير آله لتسميد محاصيل الخضر بالكمبوست}

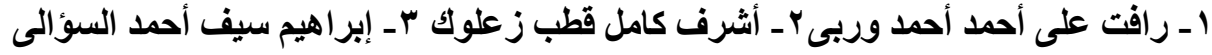

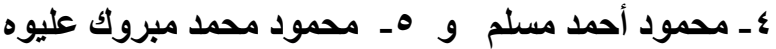

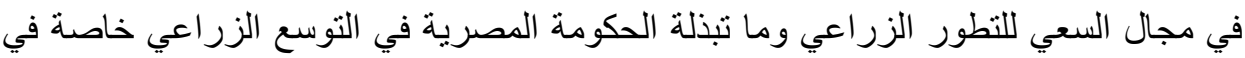
مجال زيادة الرقعة الأفقية المزروعاه وذلك عن طريق زيادة الأر اضي المستصلحة و والزيادة

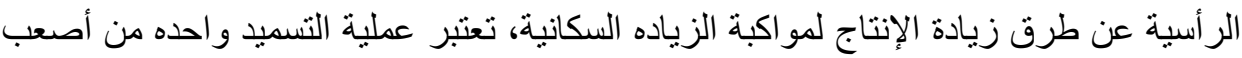
العمليات التي تواجه المزارع المصري في الوقت الحالي وتمثل عبأ إقتصاديا لنقص الإيدي

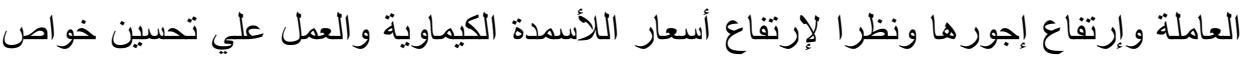

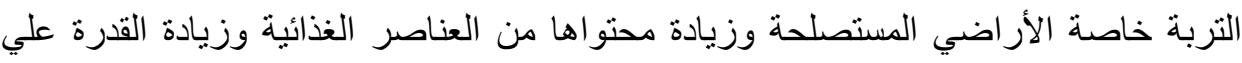

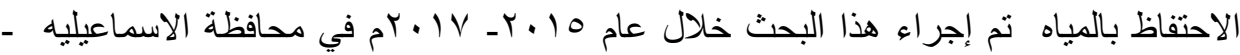

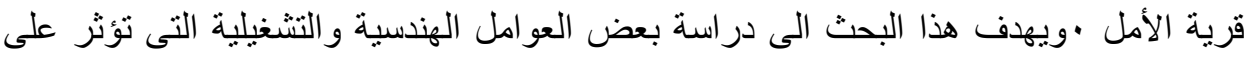

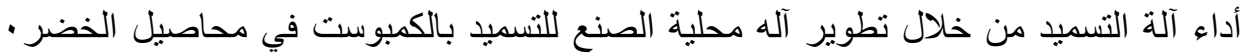
وللوصول الى هذا الهدف من خلال الآتى ـ دراسة بعض الخواص الطبيعية و الميكانيكية لسماد الكمبوست و التى تساعد فى تحديد أنسب تصميم للآله ـ تصنيع آلة محلية للتسميد بالكمبوست بسبطة وسهلة الصبانه

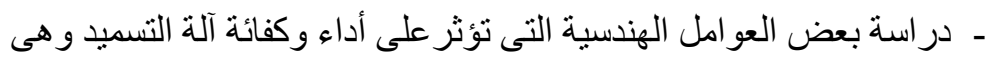

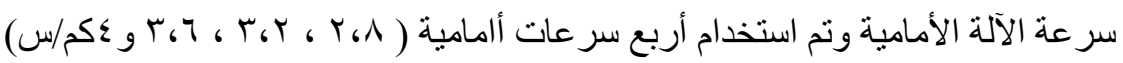

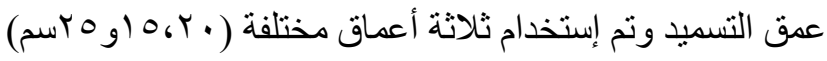

فتحه التغذية للآله وتم إستخدام ثلاثة فتحات للتغذية ( •0 ، . او ـ 1 سمب)

قطر طاره علي عجله الأرض لنقل الحركه للقلاب (0 ا وهب سم )

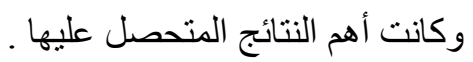

ا ـ انتاجية الآلة تزيد مع زيادة فتحة التغذية و عمق التسميد وتقل مع زيادة السر عة الامامية للآلة وقطر طارة نقل الحركة من عجلة الارض للتغذيه ، وكانت أعلى إنتاجية للتسميد

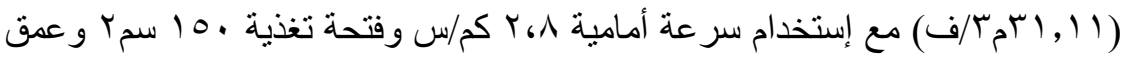

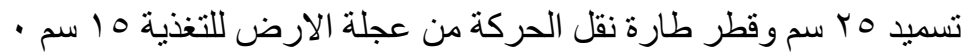

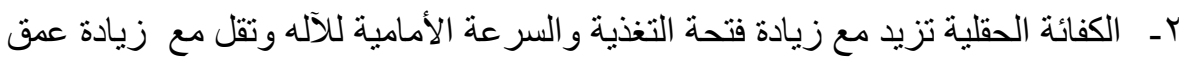
التسميد وقطر طاره نقل الحركة من عجلة الارض للتغذيه مع كل التجارب.

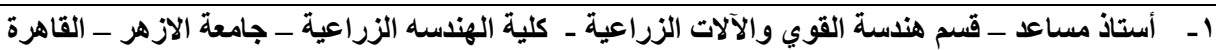

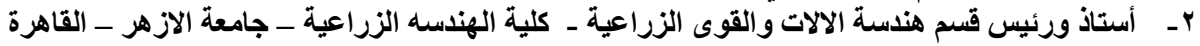

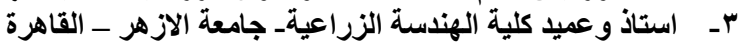

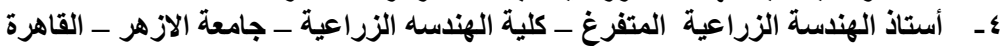
هـ ـ طالب دراسات عليا قسم الهندسه الزراعية - جامعة الازهر - القاهرة
} 


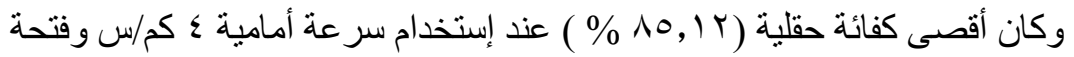

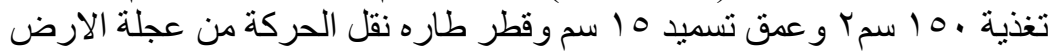
للتغذيه 10 سم .

r- الطاقة النو عيه المطلوبة نزيد مع زيادة عمق التسميد وقطر طاره نقل الحركة من عجلة

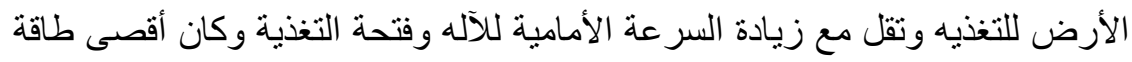

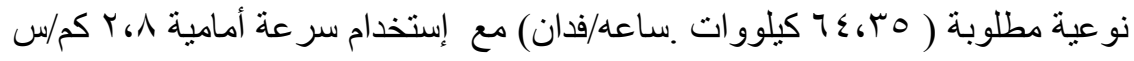

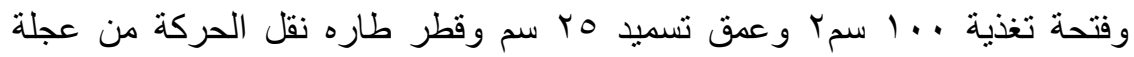

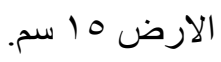
ع - نسبة تجانس توزيع السماد تزيد مع زيادة فتحة التغذية وتقل مع زيادة السر عة الأمامية للآله و عمق التسميد وقطر طاره نقل الحركة من عجلة الأرض للتغذيه وكان أعلي نسبة ونية تجانس لتوزيع السماد ( (

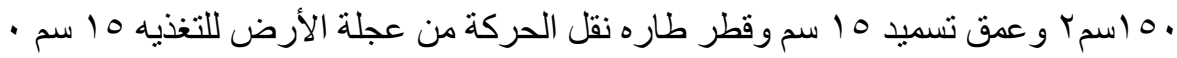
هـ - حقق إستخدام الآله المطوره إنخفاض بمقدار (Tor\%) فى التكاليف الكليه لعمليه التسميد مقارنه بالطرق التقليديه.

7- ويوصي البحث بإستخدام آله التسميد عند سرعة أمامية ع كم/س و عند فتحة تغذية • 1 اسم و عمق تسميد 10 سم وقطرطارة نقل الحركة من عجلة الارض للتغذية 10 سم

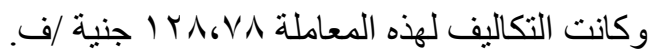

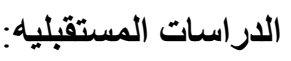

ا - زيادة عرض التشغيل عن طريق عمل وحدنين تسميد

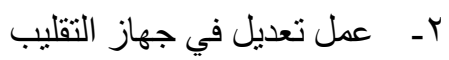
r- التحكم الهيدرولكي فى العمق و مستوى التغطيه علي السماد 